\title{
Sciendo
}

\section{The implementation of policy for the appointment of government employees with work contract in New State Universities (A Study in Borneo Tarakan University)}

\author{
Tri, SUSILO, \\ Graduate Program of Higher Education Management, Faculty of Administrative Studies, \\ Brawijaya University, Malang, East Java, Indonesia \\ trisusilo15@gmail.com \\ Bambang Santoso, HARYONO, \\ Department of Public Administrative Science, Faculty of Administrative Science, \\ Brawijaya University, Malang, East Java, Indonesia \\ bambangsfia@ub.ac.id \\ Ainul, HAYAT, \\ Department of Public Administrative Science, Faculty of Administrative Science, \\ Brawijaya University, Malang, East Java, Indonesia \\ ainul_h_fia@ub.ac.id
}

\begin{abstract}
This research investigated the implementation of policy for the appointment of lecturers and education staffs in Borneo Tarakan University as government employees based on work contract. One of the attempt made by the government to evenly provide higher education access throughout Indonesia was by converting several private-owned universities into new state-owned universities. The policy explained that all properties, students, rights and obligation which had been under private institutions' responsibility were then transferred to the government. However, this policy excludes the transfer of employees who work in the universities. The policy also mentions that all staffs are required to carry out their regular works until new regulations are released. Unfortunately, this policy often led to issues regarding the certainty of employee's status at work as. After going through a complex process, Presidential Regulation Number 10 of 2016 has been released, in which it is stated that all lecturers and education staffs are appointed as government employees based on work contract. Despite the release of this regulation, until the time this research was conducted, the appointment had not yet been carried out. This descriptive qualitative research has revealed that the policy has not yet been well administered in Borneo Tarakan University due to some problems.
\end{abstract}

Keywords: Government employees based on work contract, New state-owned universities, Borneo Tarakan University

JEL Classification: D72, D73, J18, P16 


\section{Introduction}

Government Employees based on Work Contract or Pegawai Pemerintah dengan Perjanjian Kerja or PPPK refers to any Indonesian citizen who fulfills certain criteria and is appointed based on work contract to work for the government as government employees for certain period of time to carry out government duties as stated in Act Number 5 of 2014. The appointment of PPPK is a strategy taken by the government to address the issues regarding the status of lecturers and staffs who work for new state-owned universities.

This policy is ruled in the Presidential Regulation Number 10 of 2016 concerning the status of lecturers and staffs in thirty five new state-owned universities and in the Ministerial Regulation of the research, technology, and higher education ministry Number 38 of 2016 concerning the procedure of appointment and work termination of lecturers and education staffs as government employees based on work contract in thirty five new state-owned universities.

As a public policy, the presidential regulation number 10 of 2016 aims to provide legal certainty for the work status of lecturers and education staffs in new state-owned universities. Whilst, the ministerial regulation number 38 of 2016 regulates the mechanism of the appointment. Jenkins $(1978$, p. 15) stated that public policy is a set of comprehensive decision taken by political actors to achieve certain objectives based on the proper procedure.

These followings are the procedure of the appointment.

- The appointment of Verification Team by the ministry that will verify and validate registrants' data.

- Issuing the letter of request as PPPK and enclosed with all necessary documents.

- The documents that have been considered complete and have passed the verification and validation are announced by rectors to the ministry through the head of verification team.

- The documents that are received by the minister through the general secretary are then proposed into specific formation of PPPK lecturers and staffs in the new state-owned universities.

- The formation proposal is then sent to the minister to be authorized after conducting proper coordination with the ministry of state civil apparatus.

Even though the procedure has been properly done, the process of PPPK lecturers and staffs in Borneo Tarakan University could not be administered yet. 
Whereas, based on the ministerial regulation number 38 of 2016, this appointment was expected to finish by February 3rd 2017.

Regarding to those issues, research problems were formulated as how is the implementation of the policy and what are the obstacles for PPPK appointment in Borneo Tarakan University.

\section{Theoretical Review}

\subsection{Public Policy}

The policy of PPPK appointment in Borneo Tarakan University was taken by the government to address the problems related to the uncertainty of employees' status in Borneo Tarakan University. This policy was chosen as the option considering the new regulation concerning the state's civil apparatus. This phenomena is stated by Thomasy R Dye (1992) in Anggara (2014) that "Public policy is whatever the government choose to do or not to do", implying that any policy is taken because it has certain objective.

The main objective of this policy is to give legal certainty upon the status of lecturers and staffs who work for new state-owned universities as the consequence of ownership shift. As a follow up action, the government has enacted the Presidential Regulation Number 10 of 2016, followed up with the Regulation of the Ministry of Research, Technology and Higher Education Number 38 of 2016 concerning the decision to appoint the employees as PPPK.

This action is the advancement of the previous policy in the form of Presidential Regulation Number 65 of 2010 concerning the conversion of Universitas Bangka Belitung, Borneo Tarakan University and Universitas Musamus from private-owned university to state-owned university. This policy goes in line with Anderson's view (1970) cited in Anggara (2014, p. 35), explaining that the PPPK appointment in Borneo Tarakan University is developed from the previous policy taken by the president concerning the conversation.

\subsection{Policy Implementation}

Regarding to several literatures on public policy phases, the policy of PPPK appointment is in the implementation step. The implementation of this policy is the follow up action of the regulation issued by the government concerning the uncertainty of workers' status in Borneo Tarakan University. 
This also goes in line with Wahab (1997, p. 64) who stated that implementation is a process to carry out certain policy. Whilst, Mazmanian and Sabatier (1983), Goggin (1990) and Van Horn (1975) in a book compiled by Agustino $(2017$, p. 128$)$ explain that policy implementation is any action made by individuals, officials, government groups or private parties that is meant to achieve certain predetermined objective. Based on those views, it can inferred that the appointment of PPPK in Borneo Tarakan University is the implementation of the previous Presidential Regulation number 10 of 2016 and the regulation issued by the ministry of research, technology and higher education Number 38 of 106 carried out by actors to achieve the predetermined objectives.

In regards to the statement made by Mazmanian and Sabatier (1979) in Wahab (1997, p. 68), detailed explanation on the term is "the execution of various decisions that can be in the forms of laws, government regulations, presidential regulations, ministerial regulation, court decisions and so on". Mazmanian and Sabaier also explained that the decisions and regulations are meant to address certain problems or achieve certain objectives which also includes the implementation process. Both Presidential Regulation Number 10 of 2016 and Ministerial Regulation Number 38 of 2016 also contain aspects mentioned above

As a general public policy, the appointment of PPPK in Borneo Tarakan University is also prone to failure. Despite the clear mechanism that has been provided, problems might occur during the process.

Edward III (1980) mentioned four factors influencing the implementation of a policy including Communication, Resources, Bureaucracy, and Disposition.

\section{Research Method}

This research was conducted using a descriptive qualitative method. Creswell (2010) cited by Ahmad (2015, p. 52) stated that qualitative research is a research method that aims to explore and understand certain phenomena that occurs among a group of individuals or people which is assumed to rise from social or human issues. Meanwhile, Bungin $(2001$, p. 48) staid that descriptive qualitative research is intended to explain and describe certain situation that occurs in a society as a research object. Essentially, this type of research aims to identify, understand, describe and discuss the implementation of PPPK appointment in Borneo Tarakan University and the obstacles that occurred during the process. 


\section{Results and Discussions}

The implementation of PPPK appointment in Borneo Tarakan University is regulated by the Presidential Regulation Number 10 of 2016 and the Ministerial Regulation Number 38 of 2018. Those two legal regulations explain that to be appointed as PPPK, lecturers and education staffs have to pass a series of steps as previously explained. Based on the results of interview and field observation done in this research, the implementation of this policy was unstable as it faced deadlock. Referring to what is said by Edward III, the researchers successfully identified four factors that caused those failures.

\subsection{Communication}

Communication is an important part in the implementation of certain policy as it allows the implementation process to occur as planned. The implementation of certain policy is regarded effective is decision makes understand their jobs and are able to maintain good and consistent communication.

Based on the results of this research, the communication during the implementation of PPPK appointment in Borneo Tarakan University did not run effectively as the communication was rather unclear and inconsistent. (1) In the aspect of clarity, it is found that the actors who are involved in the implementation of this policy did not understand the Presidential Regulation number 10 of 2016 that they failed to identify the problems to solve. The concept of PPPK appointment stated in the Presidential Regulation also contradicted the law concerning State's Civil Apparatus. (2) The communication did not run consistently. This could be seen from the change in the initial objective. The regulation was initially made to appoint the lecturers and staffs in new stateowned universities based on a work contract. In the implementation, lecturers and staffs were appointed as permanent non-civil apparatus employees.

\subsection{Resources}

In the implementation of a policy, resources give significant contribution. The resources used in the appointment of PPPK in Borneo Tarakan University included human resource, financial resource, and authority resource. The information collected in this research showed that (1) The resources used for the implementation of PPPK appointment policy in Borneo Tarakan University in the scope of the ministry of research, technology and higher education were limited. Inadequate support from the staffs became the factor that lead to the failure of 
the policy implementation. (2) Financial resource. The unclear financial source in funding the PPPK appointment also hindered the PPPK implementation in Borneo Tarakan University. This might occur as the PPPK program is not only limited to PTNB, but it is also for other professions such as teacher, midwife, nurse, and other honorary employees of regional government. Hence, this program takes up high cost. (3) Authority resource.

The authority to implement PPPK program was not held by the ministry of research, technology and higher education as the concerned party. It became problematic when other institutions with equal position had to be involved in the process.

\subsection{Disposition}

This value reflects the attitude and commitment of the program executors toward the implementation of this program. The success of a policy requires strong commitment from the executors to achieve the objectives as planned. Unfortunately, several executors showed their resistance and disagreement toward the policy. This issue occurred as they perceived that the values of this policy do not match with the value system that applies. The results of this research showed that those dispositions made executors' performance ineffective as they were not pleased to do this duty. Those dispositions also led to disagreement and dislike toward the values of this policy which negatively affect the Bureaucracy.

They believed that this policy cut off the career path among state's civil servants, causing smaller chance for them to achieve higher positions.

\subsection{Bureaucracy Structure}

Another key aspect in the implementation of a policy is the executor. A policy can be implemented by organizations, government institutions, government officials or non-government organizations. Mostly, the implementation of various policies, including PPPK appointment policy is administered by government institutions, which includes individuals who work within a system called Bureaucracy. However, regardless of how executors comprehend the program, without adequate support from the Bureaucracy, the implementation of a policy would likely to fail.

According to Edward III, there are two characteristics that guarantee better performance of a Bureaucracy. The two aspects include fair job distribution (fragmentation) and proper Standard Operating Procedure (SOP). 
It is found out that the design of PPPK policy for new state-owned universities was not created based on proper SOP mechanism and law. This fact was revealed based on the results of interviews administered with the informant from the Ministry of Research, Technology and Higher Education who admitted that the policy was not properly designed. In line with this view, the informant from the Ministry of State's Civil Apparatus Employment stated that the policy related to PPPK appointment was intended to accelerate the development but it did not fulfill the proper procedure.

As pointed out by Agustino (2017, p. 141) a policy in which many parties are involved makes its implementation challenging. He believed that a policy that requires good cooperation among many parties tend to make its implementation less conducive. Moreover, when it involves many parties that held equal authorities. This issue also led to the unavailability of one clear SOP in the Bureaucracy structure of the executors in implementing the PPPK appointment policy in Borneo Tarakan University.

Other factors have also been identified to add up to Edward's points regarding the implementation of PPPK appointment policy in unversitas borneo tarakan as follows.

1. Unavailability of supporting regulations

Within the hierarchy system that applies in Indonesia, every law contains different ideas based on its own level. A legal regulation needs legal basis to explain its essentials. A law cannot stand independently without being supported by other regulations. Similarly, the presidential regulation number 10 of 2016 becomes the basis used by the government to appoint PPPK in Borneo Tarakan University. The act number 12 od 2011 mentions the types and hierarchy of law system that applies in Indonesia.

- The 1945 Constitution of Indonesia;

- The Provision of the People's Consultative Assembly;

- Laws/Government Regulations in Lieu of Law;

- Government Regulations;

- Presidential Regulations;

- Provincial Regional Regulations;

- District Regional Regulations;

Even though the PPPK appointment policy is supported by the ministerial regulation No. 38 of 2016, its implementation should also regard the laws concerning state's civil apparatus. To be able to carry out the PPPK appointment 
process, several supporting regulations were needed. The supporting regulations needed include regulations regarding the management of PPPK, presidential regulations regarding functional positions that can be occupied by PPPK, presidential regulations governing salary and allowance for PPPK, and so forth. These aspects appeared as the obstacles that hindered the process of PPPK appointment policy implementation at Borneo Tarakan University.

2. Presidential Initiative Permit

One of the inhibiting factors in the process of PPPK appointment policy implementation in Borneo Tarakan University was related to presidential initiative permit. This presidential initiative permit was needed to revise the presidential regulation No. 10 of 2016 which substantially contradicted the legislations. Based on the legal system in Indonesia, Act No. 12 of 2011 in Article 28 paragraph 1 states that in certain circumstances, ministries or non-ministerial government institutions may submit government regulation drafts beyond the planning of Government Regulations Drafting.

The Government Regulation draft in certain circumstances as referred to in paragraph (1) can occur to answer the needs of the Law or the decision of the Supreme Court. The draft can be later conveyed by the president through the Minister of State Decree as stipulated in Presidential Regulation No. 24 of 2015 concerning the Ministry of State secretary. Based on this minister's decree, the permission of the initiative as intended can be submitted to the cabinet secretary for approval as stipulated in presidential regulation No. 25 of 2015 concerning the cabinet secretariat. After obtaining the approval, the draft can be brought to the inter-ministerial committee for harmonization, drafting and submission to the President with mutatis mutandis as stipulated in Presidential Regulation No. $68 / 2005$ concerning procedures for preparing the drafts of laws, government regulation in lieu of law, and presidential regulations. The term mutatis and mutandis according to Rahundoko is interpreted as "with necessary or important changes". (www.hukumonline.com.10 / 5/2010) accessed on February 28th, 2019.

It can be inferred from the above explanation, obtaining presidential initiative permit is rather complicated due to the complex mechanism and drafting process of the new regulations. Some institutions are involved in this process of drafting which is later forwarded in an inter-ministerial committee to carry out a harmonization process, and the draft of presidential regulation is submitted to the president. Even the president will not find it easy to give approval and permit to revise it. The President will have to consider many aspects related to the proposed 
clauses for revision processes such as juridical aspects, sociological aspects, financial aspects, etc.

Moreover, the draft should passed the cabinet secretary which is known to have strong political intervention before it goes straight to the President. In other words, obtaining presidential initiative permit requires two mechanism processes; bureaucratic and political mechanism processes.

The current information obtained in this research showed that there were no signs of presidential initiative's permission to revise the presidential regulation number 10 of 2016. As this deals with president's prerogative rights, no institutions or ministries are allowed to interfere this process to make the prepermit immediately issued. These issues then became the inhibiting factors for the implementation of PPPK appointment policy in Borneo Tarakan University.

\section{Conclusions}

It can be generally concluded from those facts that he implementation of PPPK appointment policy in Borneo Tarakan University has failed or unsuccessfully administered by the time this research is conducted. There have been some inhibiting factors and obstacles that led to this failure. Six major factors have been identified as follows.

- Unclear and inconsistent communication process,

- Limited human resource, incompetent human resource and the absence of authority.

- Unavailability of clear SOP in the Bureaucracy structure

- Half-hearted attitude from the executors in implementing the policy,

- Unavailability of supporting regulations regarding this PPPK appointment policy,

- Issues regarding the process to obtain revision permit for the presidential regulation Number 10 of 2016.

Furthermore, Wahab $(1997$, p. 62) has mentioned three fundamental reasons that lead to failures in the implementation of a public policy which are Bad Policy, Bad Execution, and Bad Luck.

\section{References}

[1] Jenkis, W.I. (1978). Policy Analysis. Oxford Martin Robertson.

[2] Anggarai, S. (2014). Kebijakan Publik. Bandung.Pustaka setia. 
[3] Wahab, S.A. (1997). Analisis Kebijaksanaan Dari Formulasi Ke Implementasi Kebijaksanaan Negara. Jakarta: Bumi Aksara.

[4] Cresswell, J.W. (2015). Research Design Pendekatan Kualitatif, Kuantitatif, Dan Mlxed. Yogyakarta: Pustaka Pelajar. Penerjemah Ahmad Fawaid.

[5] Agustino, L. (2017). Dasar-dasar Kebijakan Publik Edisi Revisi .Bandung

[6] Bungin, B. (2001). Metodelogi Penelitian Sosial-Format kuantitaif dan Kualitatif, Surabaya: Airlangga

[7] Edward III, G.C. (1980). Implementing Public Policy. Washington Congressiona IQuarterly Press

[8] Peraturan Presiden No 10 Tahun. (2016). tentang dosen dan tenaga Kependidikan pada tiga puluh lima perguruan tinggi negeri baru

[9] Peraturan menteri riset, teknologi dan pendidikan tinggi no 38 tahun (2016). tentang tata cara pengangkatan dan pemberhentian dosen dan tenaga kependidikan sebagai pegawai pemerintah dengan perjanjian kerja pada tiga puluh lima perguruan tinggi negeri baru.

[10] Undang-undang No 12 Tahun (2011). Tentang Pembentukan Peraturan Perundang-undangan

[11] https://www.hukumonline.com/klinik/detail//t4bdfcd4e7c122/pengertian-mutatis-mutandis 